\title{
食料と栄養の安全保障 土壌の改善と生産性の向上 \\ (仮訳)
}

\section{要約}

土壤、水、エネルギーは食料安全保障にとって不可欠な資源である。土壤資源に対する人為的負荷は危機的限界に達しつつあ

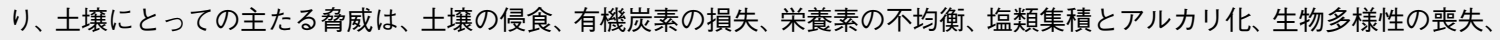
污染、酸性化、緻密化、都市化である。こうした状況を踏まえ、S2O は持続可能な土堙管理のために次の具体的な提言を行う。 1.より有効な土壤に関するガバナンスの推進

都市の無秩序な膨張を抑制し、気候変動に対応した土壤管理の実用的な戦略策定を優先的に実施すべきである。定点観測や 恒久的な土壤観察は、土壤修復プログラムの査定や土壤劣化の基準を知る上で必須である。土壤、水、作物データを科学的な モデルに組み込むことにより多様な計画策定やそれらの計画実施を支援することが可能となる。科学は、政府や市民社会によ る具体的な政策の実施、特に土壇保全や保護の法制化への関心を喚起するために必要である。重要な土壤の役割について一般 の意識を高めるためには教育やメディアを通じた啓発が求められる。持続可能な土壤管理教育プログラムの実施も強く要望す る。

\section{2. 特定領域における土壇情報の深化}

包括的な 3D高解像度 $(30 \mathrm{~m})$ のデジタルマッピングは、土壤特性の研究やそれに基づく実践管理に関する知識を獲得する ために必要である。3 Dデジタル土壤特性図を気象観測や適正作物データと統合すれば、水や施肥の効率を改善し、国内や域 内の条件に適した最適な栽培法を確定することができる。これらの土壤図や作物適合図は、リアルタイムのビッグデータを活 用した最新の土壤計測によって補完されることが必要である。土䁃に関する研究課題は以下のとおりである。(a) 土潩微生物 丵やその多様性が土壤の機能及び植生や人体の健康に及ぼすメカニズムの解読、(b) 効率的で効果的な肥料の再利用と、生産 目標を達成するための世界的な制限要因に関する研究、(c) 長短期間の炭素貯留、土壤有機物の保存と劣化土壤の修復に関す る研究、(d) 天敵を利用した生態学的手法と低毒性及び急速分解型殺虫剤の高度限定使用による病害虫対策を含む農薬の毒性 緩和手法の開発。

3. 国際的な科学協カプログラムの強化

土壤の持続的な管理に関する国際的な科学協力プログラムを推進する。低開発国において専門家や科学者を養成する博士、 ポスドク・プログラムは特に設置・推奨されるべきである。

土㙵は人間活動により変化する脆弱な地球の表面形 成物である。世界土壤憲章が記しているとおり「土潩は 地球上の生命の基盤であるが、土壌資源にかかる人為 的負荷は限界に到達しようとしている」(FAO 2015a)。 人類の文明を支えるためには、土壤に関する知識とそ の保全が不可欠である。

農業分野において土壤に関する課題は、近年大幅に増 加している。2015年の世界土壤資源報告は、土㙵に対 する主な妿威として、土䁃の侵食、土壤有機炭素の損失、 養分不均衡を挙げている。他の脅威としては土懔の塩 類集積とアルカリ化、土壌生物多様性の喪失、土畩污染、 土㙵酸性化、土壤の圧密化が含まれる（FAO 2015b）。 さらに、質の高い土壌が、都市化や工業開発によって 失われつつあることも問題である。FAO（2015b）は、 世界の土壤の 33 パーセントはこれらの脅威によって中 程度あるいは強度に劣化していると報告している。

土壤、水、エネルギーは世界の食料安全保障を確保 するために不可欠な資源である。FAOは、地球の食料 生産量の約 95 パーセントが直接・間接的に土壤から生 産されていると試算している。現在の人口増加率と想 定される食生活の変化は、2050年までに世界規模にお いて今より 60 パーセント以上の食料を生産する必要が あると予測されており、世界の食料安全保障のために は利用可能な土壌の保全を優先させねばならない。

土壤管理は、持続可能な農業はもとより自然な生態 系の維持と気候調節など土壌の幅広い機能にまで、そ
の概念の範囲を広げていくことが必要である。世界の 土㙵の持続可能性を学際的にとらえるためには、生物 物理学的、経済的、社会及び政策的側面からの定量化 が求められている。

土壤を持続可能たらしめるためには、自然資源の私 有、共有を問わず、模範的な営農技術に関する知見、 その制度化と普及教育が必須である。また、そこから 生まれる新たな情報への広範なアクセスも不可欠であ る。

$\mathrm{FAO} \mathrm{UNCCD}$ な゙の国連機関の報告書には、多様 な持続可能な土㙥管理のアプローチが示されている。 これらの目的は、土壤侵食の制御、土㙵有機物の増強、 土潩炭素の蓄積促進、土䁃被覆の制限、土壤生物多様 性及び長期的な土壤の理化学的肥沃度の向上である。 これらの持続可能な土壤管理のアプローチは全て、科 学的で、立証にもとづいた在来の知識を用いることに より、栄養価の高い食料供給の維持・増強が可能であり、 かつ、気候変動を緩和し、自然生態系のサービスを保 全することにも貢献するものである、という前提を共 有している (FAO 2015b)。

こうした観点から、S 20 各国アカデミーは、持続可 能な土㙵管理のための証拠基盤の深化と農業生産性の 向上を目指して次の提言を行う。

1. より有効な土㙥に関するガバナンスの推進は、上記 の脅威に対する土壤保護を伴う。土壤ガバナンスと 
して最優先に行うべきことは、都市部の無秩序な拡 大を抑止し、気候変動に適応した土䁃管理の戦略を 考案することである。

定点観測に基づく土壇観測や恒久的な観察は、土 壤修復プログラムの検証のために必要であり、土壤 劣化に関する原因究明にもつながる。指針は政策決 定者や当事者が適切な情報を得るために地域や地元 の状況に則して定められなければならない。土壤、水、 作物デー夕を科学的に基づいたモデルへと統合する ことにより、計画案を策定し、決定することが可能 となる。科学は、政府や市民社会による政策の実施、 特に土潩保全や保護の法制化への関心を喚起するた めに必要である。土壌の本質的な役割について一般 市民を啓発する手段として、土壤教育（学校やメディ ア）の推進が必要である。

持続可能な土潩管理に関する農業者を対象とした 教育プログラムの実施が強く求められる。

2. 土壤知識の実質的な進歩とは、土壤デー夕を決定手 段に組み込むことである。

包括的な $3 \mathrm{D}$ 高解像度 $(30 \mathrm{~m})$ デジタルマッピン グは、土潩特性の研究やそれに基づく実践管理に関 する知識を獲得するために必要である。この努力は、 土壌の欠乏状況を確認し、土壌を改善する新しい方 法を実証するために、世界の全地域に対象を拡大す べきである。3Dのデジタル土壤特性図を気象観測や 適性作物データと統合させれば、水や施肥の効率を 改善し、国内や域内の条件に最も適合した栽培法を 確定することができる。これらの土壌図や作物適正 図は、リアルタイムのビッグデータを利用した最新 の土壤計測によって補完されることが必要である。 そうすることにより、デジタル農業の実現が加速化 されるであろう。その結果、生産性を維持・改善し ながら、投入物を削減し、環境を改善することがで きる。

土壌に関する今後の研究課題を次に挙げる。

a）土壤の微生物叢とその多様性が、土壤の機能性、 植生及び人類の健康にどのようなメカニズムで影 響を与えるかについては、現代の生物学において 注目されている研究課題の一つである。最新の高 速塩基配列解析は、農業、気候、医療の基礎とな る一連の土壤プロセスの遺伝学的、酵素学的制御 を定量化して研究する際の基本となるであろう。 この複雑な研究分野は未だ緒に就いたばかりであ るが、これらの研究は最終的には土畩の生産性を 高め、微生物を用いた污染物除去による劣化土壤 の修復に役立つ可能性を秘めている。

b）高生産性を実現するための世界的な制約となって いる肥料の効率と効果的な再利用法に関する研究。

c）短期 - 長期的な炭素貯留、土袞有機物の保護、及
び劣化土壤の修復に関する研究。

d）農薬の毒物学的及び環境学的側面ならびに持続的 農法に焦点を当てた土䁃污染の軽減と回避に関す る研究。例えば、天敵を利用した生態学的病害虫 駆除法、低毒性あるいは急速分解性殺虫剂利用法、 高度標的限定施用法など。

\section{3. 持続可能な土壤管理の国際的な科学協カプログラム を強化する。}

低開発国の専門家や科学者の能力を高める博士及び ポスドクのためのプログラムを特に設置・促進すべき である。

\section{参考文献}

FAO (2015a), Revised World Soil Charter (「改訂世界土壤憲章」)

FAO (2015b), Status of the World' s Soil Resources（「世界土袞資 源報告」)

FAO (2015c), Healthy soils are the basis for healthy food production (「健全な土壌は健全な食料生産の基盤」)

UNCCD (2017), The Global Land Outlook(「世界土地概況」) (United Nations Convention to Combat Desertification「国連砂漠化 対処条約」) 